\title{
The Effects of Angiotensin II Blockade and Nephrectomy on the Renin-Angiotensin- Aldosterone System in the Newborn Lamb
}

\author{
SHARON R. SIEGEL AND DELBERT A. FISHER \\ Fetal-Maternal Research Laboratories, Departments of Pediatrics and Obstetrics \& Gynecology, UCLA-Harbor \\ General Hospital, Torrance, California, USA
}

\section{Summary}

Six newborn lambs were studied during continuous infusion of saralasin acetate, $5 \mu \mathrm{g} / \mathrm{kg} / \mathrm{min}$ for $135 \mathrm{~min} ; 40 \mathrm{~min}$ after beginning saralasin, furosemide $(2 \mathrm{mg} / \mathrm{kg})$ was injected over 1-2 min. In addition, six anephric lambs were studied after injection of furosemide. Plasma renin activity (PRA) increased from $23 \pm 2.7 \mathrm{ng} /$ $\mathrm{ml} / \mathrm{hr}(\mathrm{M}$ and $\mathrm{SE})$ to $85.8 \pm 16.5(P<0.05)$ during infusion of saralasin alone and remained at this level after injection of furosemide. PRA did not increase above base line after injection of furosemide in the anephric lambs. Blood pressure dropped after saralasin infusion in the normal lambs $(P<0.05)$, and after furosemide injection $(P<0.05)$ in both groups. Plasma aldosterone concentrations did not increase in response to furosemide in either group. The results suggest that angiotensin II is important in maintaining blood pressure in the newborn and exerts antagonistic effects on the renal renin secretion mechanism.

\section{Speculation}

The renin-angiotensin-aldosterone system is activated in the normal newborn. Possible reasons for the activation include decreased circumferential tension of small arteries and salt wasting.

It has previously been shown that PRA levels and aldosterone concentrations are relatively high compared to the adult in the newborn lamb as in the newborn human infant $(2,10,16)$. The reason for the high levels is not clear. The fact that PRA and aldosterone both respond to furosemide stimulation during the neonatal period (17) indicates that the renin-angiotensin-aldosterone cascade are linked to a juxtaglomerular cell stimulus. In addition, serum aldosterone levels qualitatively fluctuate appropriately to variations in sodium intake and excretion (16). It has been shown in adult humans and dogs $(3,6,12,13)$ that angiotensin II inhibits renin secretion. The present study was conducted to investigate whether angiotensin II inhibits renin by negative feedback and importantly influences blood pressure in the newborn lamb. We also hoped to determine whether biologically active renin originates in other tissues than the newborn kidney.

\section{MATERIALS AND METHODS}

Six normal lambs and six anephric lambs were studied during the first 2 weeks of life. Carotid arterial and jugular venous catheters were placed 1 or 2 days before the study. The lambs were separated from their mothers approximately $2 \frac{1}{2} \mathrm{hr}$ before study. They were kept warm and quiet during the experiment. In the 6 normal lambs, 2 base line blood samples were collected for PRA and for plasma aldosterone, sodium $(\mathrm{Na})$, and potassium $(\mathrm{K})$ concentration measurements. This was followed by a continuous infusion of 1-sarcosine, 8 -alanine angiotensin II (saralasin àcetate)
$5 \mu \mathrm{g} / \mathrm{kg} / \mathrm{min}$ in $10 \mathrm{ml}$ of saline for $40 \mathrm{~min}$. Furosemide, $2 \mathrm{mg} / \mathrm{kg}$, was then injected over a 1-2 min period while the saralasin infusion continued for another $95 \mathrm{~min}$. Blood samples were collected for repeat measurements of PRA, aldosterone, NA, and K at 10-min-intervals during the saralasin only infusion and at 8,20, 35,65 , and 95 min after furosemide plus saralasin. Each blood sample was replaced with an equal amount of saline. A control experiment showed no hormonal changes from the amount of blood drawn. The six nephrectomized lambs were clinically well and studied $24 \mathrm{hr}$ after the kidneys were removed. Blood pressure was measured via a carotid artery catheter using a water manometer (11). PRA (without added renin substrate) $(5,15)$ after generation of angiotensin I, and aldosterone (7) after column chromatography, were measured by radioimmunoassay. $\mathrm{Na}$ and $\mathrm{K}$ were measured by flame photometry. Plasma renin substrate was obtained from the anephric lambs by the method of Skinner (18). Cortisol was measured by radioimmunoassay (14).

\section{RESULTS}

Table 1 shows the PRA response to furosemide in newborn lambs during saralasin infusion with and without added renin substrate. PRA without added substrate increased from $23 \pm 2.7$ $\mathrm{ng} / \mathrm{ml} / \mathrm{hr}(\mathrm{M}$ and $\mathrm{SE})$ to $85.8 \pm 16.5(P<0.05) 30 \mathrm{~min}$ after beginning saralasin infusion alone and mean values remained elevated in the $79.5-96.6 \mathrm{ng} / \mathrm{ml} / \mathrm{hr}$ range until $35 \mathrm{~min}$ after the furosemide was injected. Blood samples drawn at 10,20,30, and 40 min after saralasin alone in three animals showed maximal PRA levels by the 10-min-sample. By $95 \mathrm{~min}$, the value had fallen to $54.9 \mathrm{ng} / \mathrm{ml} / \mathrm{hr}$. With the in vitro addition of renin substrate, the PRA increased from $23.7 \pm 2.1$ to $85.2 \pm 13.9 \mathrm{ng} / \mathrm{ml} / \mathrm{hr} 30 \mathrm{~min}$ after beginning the saralasin'infusion. Eight $\mathrm{min}$ after the injection of furosemide, PRA increased to $170.4 \pm 25.8 \mathrm{ng} / \mathrm{ml} / \mathrm{hr}$ and mean values remained in the range of 170-187.2 throughout the remainder of the study period. Figure 1 compares the PRA responses to furosemide in the saralasin treated normal lambs and the anephric lambs. The plotted values in the normal lambs were measured without added renin substrate. The base line PRA in the anephric lambs was $6.3 \pm 2.0 \mathrm{ng} / \mathrm{ml} / \mathrm{hr}$. There was no response to furosemide.

Figure 2 shows the blood pressure changes in the normal lambs after saralasin infusion and furosemide injection and in the anephric lambs after furosemide. Mean blood pressure in the normal lambs dropped $10 \mathrm{~mm} \mathrm{Hg}$ by $40 \mathrm{~min}$ after saralasin infusion $(P$ $<0.05$ ) and $6 \mathrm{~mm} \mathrm{Hg} 35 \mathrm{~min}$ after furosemide during continuing saralasin infusion $(P<0.05)$. A mean $6 \mathrm{~mm} \mathrm{Hg}$ fall was noted by $35 \mathrm{~min}$ after furosemide in the anephric lambs $(P<0.05)$.

Figure 3 shows the plasma aldosterone concentrations in the two groups of animals. Base line mean aldosterone levels were increased in the anephric animals: $46.5 \pm 6.1 \mathrm{vs} .17 .6 \pm 4.3 \mathrm{ng} / \mathrm{dl}$ in the normal lambs (Table 2). There was no increase in plasma aldosterone concentrations in response to furosemide in the aneph- 
Table 1. PRA response to furosemide in newborn lambs with $1-S A R, 8-A L A$, angiotensin $I I,\left(\right.$ saralasin) ${ }^{1}$

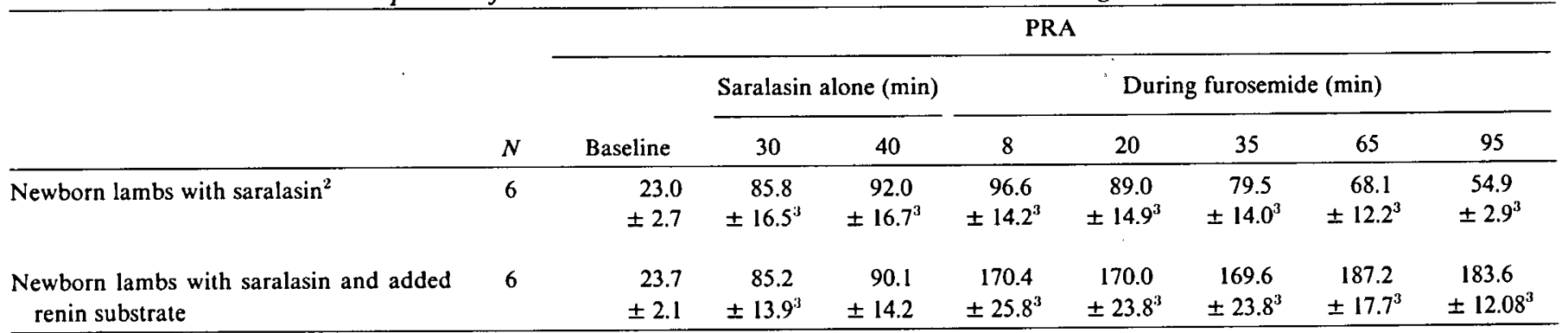

\footnotetext{
'Values recorded as mean and SEM $\mathrm{ng} / \mathrm{ml} / \mathrm{min}$.

${ }^{2}$ Saralasin plus furosemide infused for last $95 \mathrm{~min}$.

${ }^{3} P<0.05$ vs. baseline.
}

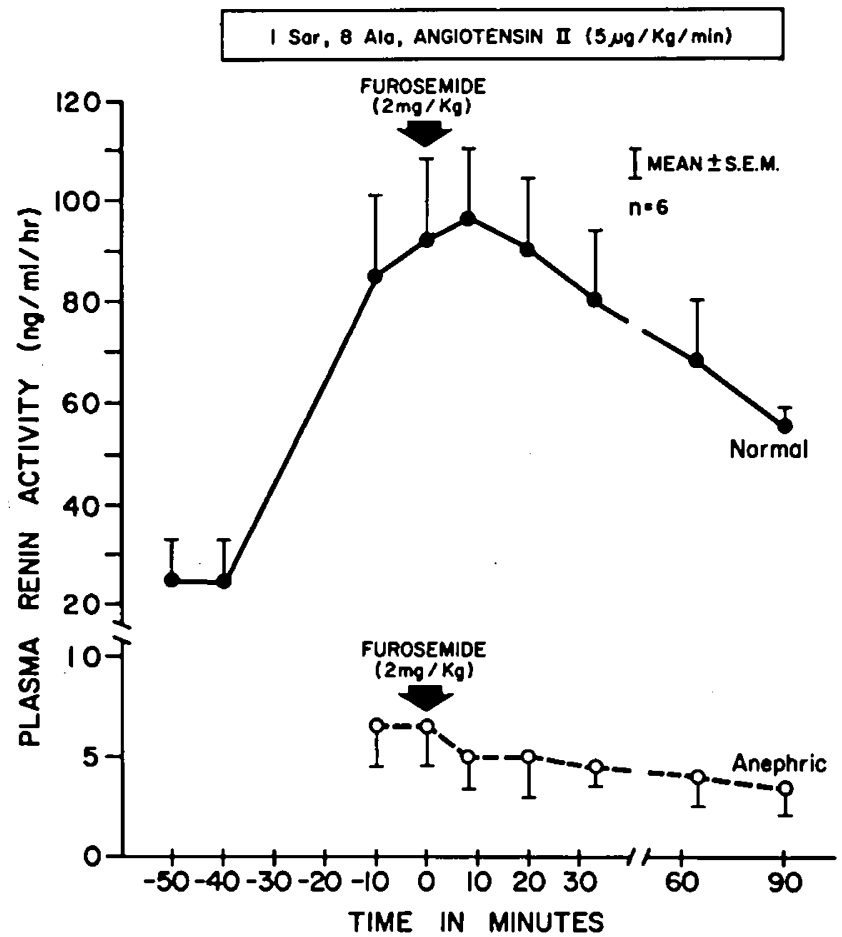

Fig. 1. PRA (ng/ml/hr) response to saralasin acetate and saralasin plus furosemide in normal lambs, and furosemide in anephric lambs. PRA increased to maximal levels $30 \mathrm{~min}$ after saralasin alone, but did not increase after furosemide in the anephric lambs.

ric lambs over the 95-min-study period or in the saralasin treated lambs during the 135-min-period of study (Fig. 3).

Table 2 shows the base line plasma cortisol, aldosterone, $\mathrm{Na}$, and $\mathrm{K}$ levels in the normal and anephric lambs. Cortisol, aldosterone, and $\mathrm{K}$ levels were higher $(P<0.01)$ and $\mathrm{Na}$ concentrations lower $(P<0.05)$ in the anephric lambs than in the normal animals.

There were no changes in blood hematocrit or plasma sodium or potassium concentrations during the furosemide or saralasin infusions in either the normal or anephric lambs.

\section{DISCUSSION}

Circulating renin, angiotensin, and aldosterone concentrations have been shown to be high in the newborn infant and newborn lamb compared to the adult in the absence of hypertension or serum electrolyte imbalance. The reason for the apparent activation of the system in the newborn is unclear. We have previously shown that furosemide increases both PRA and aldosterone levels in the newborn lamb (17), indicating that the renal juxtaglomerular cells are responsive to stimulation and that aldosterone levels respond promptly to increases in PRA. Angiotensin II infusion inhibits renin secretion in adult dogs and humans $(3,6,12,13)$. Saralasin acetate, a specific synthetic peptide competitive inhibitor

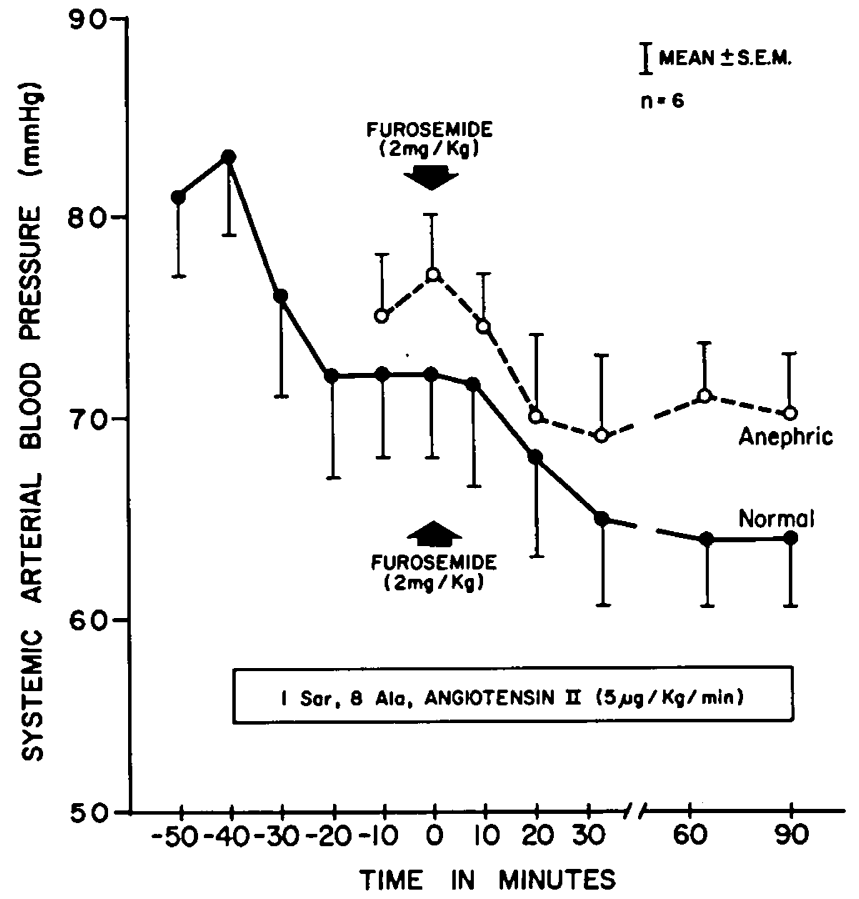

Fig. 2. Systemic arterial blood pressure response to saralasin acetate and saralasin plus furosemide in the normal lambs; and furosemide in the anephric lambs. Mean blood pressure dropped $10 \mathrm{~mm} \mathrm{Hg}$ by $40 \mathrm{~min}$ after saralasin infusion alone $(P<0.05)$ and $6 \mathrm{~mm} \mathrm{Hg} 35 \mathrm{~min}$ after furosemide during the continuing saralasin infusion $(P<0.05)$; a $6 \mathrm{~mm} \mathrm{Hg}$ fall occurred $35 \mathrm{~min}(P<0.05)$ after furosemide in the anephric lambs.

of angiotensin II, blocks this inhibitory effect of angiotensin II on renin secretion $(8,9,19)$ indicating that the effect is mediated via angiotensin II receptors. The current hypothesis is that there is a negative feedback loop between angiotensin II and renin, but the mechanism is not clear.

The present results show that normal lambs respond to saralasin infusion with a marked increment in mean PRA (Table 1), Fig. 1). It is suggestive that the newborn lamb, like the adult human or dog, appears to have an intact negative feedback loop between angiotensin II and renin. Furosemide appeared not to stimulate the system further in the absence of added renin substrate (Table 1). The addition of renin substrate revealed that maximal PRA is substrate limited as PRA rose further in response to furosemide even in the presence of saralasin acetate (Table 1). It has been shown that the renin substrate level is increased in the newborn human infant, relative to the adult $(4,10)$, and the present observation of large PRA responses to the saralasin infusion in the normal animals are consistent with this observation. Nonetheless, PRA may be substrate limited in the newborn lamb at PRA levels above $80-100 \mathrm{ng} / \mathrm{ml} / \mathrm{min}$. The mean (and SE) base line PRA level in the anephric lambs was low $(6.3 \pm 2.0 \mathrm{ng} / \mathrm{ml} / \mathrm{min})$ 


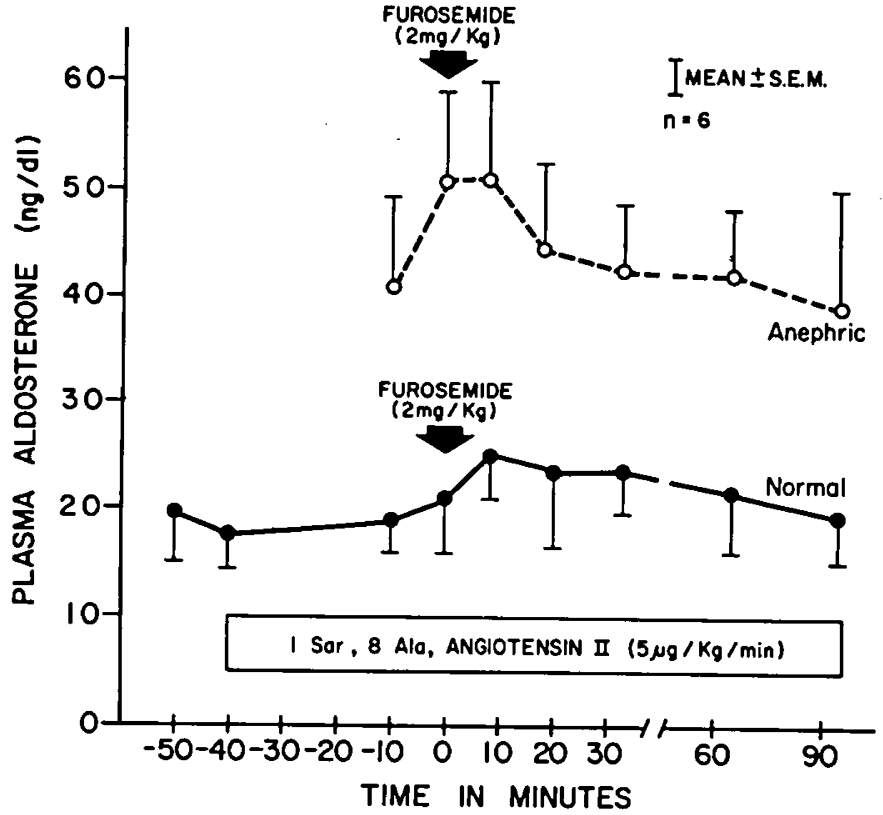

Fig. 3. Plasma aldosterone concentrations in normal lambs during saralasin acetate and saralasin plus furosemide, and after furosemide in anephric lambs. Plasma aldosterone levels did not increase after furosemide in either group of animals.

$24 \mathrm{hr}$ after nephrectomy, and there was no PRA response to furosemide in these animals (Fig. 1). These observations indicate that the kidney is the major source for the high newborn PRA levels. The low, but significant, base line PRA levels in the anephric animals at a time when circulating PRA should have disappeared may represent isorenin derived from other organs, as has been postulated for circulating PRA in the anephric human adult.

The significant decreases in blood pressure in response to saralasin acetate alone $(10 \mathrm{~mm} \mathrm{Hg}, P<0.05$, Fig. 2), and saralasin acetate plus furosemide (another $6 \mathrm{~mm} \mathrm{Hg}, P<0.05$ ) in the normal lambs in the present study support the view that the high levels of angiotensin II are important in the maintenance of peripheral vascular resistance in the newborn lamb. The fact that newborn blood pressure is low in the face of high PRA levels would suggest the possibility that vascular smooth muscle in the newborn is relatively unresponsive to angiotensin II. Whether this is the cause or the effect (tachyphylaxis) of the high circulating levels is not clear. Plasma aldosterone levels did not increase after furosemide infusion in the presence of saralasin in the normal lambs, despite the marked PRA response. This shows that saralasin acetate effectively blocked aldosterone stimulation by angiotensin II. The additional observation that furosemide alone in the anephric lamb did not stimulate aldosterone secretion further supports the view that the renin-angiotensin system stimulates aldosterone in the newborn.

Plasma cortisol, aldosterone, and $\mathrm{K}$ levels were higher in the anephric lambs than in the normal lambs $(P<0.01)$, (Table 2). The lower sodium levels in the anephric lambs may be secondary to water retention. The higher cortisol levels, representing ACTH stimulation, probably represent residual stress and pain of surgery. It has been shown in anephric man that plasma aldosterone concentrations can increase 10-fold and this increase appears to be secondary to direct stimulation by $\mathrm{K}$; aldosterone levels fall in this situation when serum $K$ is reduced. Moreover, there is no correlation between plasma aldosterone levels and posture, volume changes, or changes in plasma composition in the anephric human subject (1). Thus, the higher mean $\mathrm{K}$ levels in the anephric lambs compared to the normal lambs and/or the stress of surgery are
Table 2. Plasma cortisol, aldosterone, $N a$ and $K$ levels in the normal and anephric newborn lamb ${ }^{1}$

\begin{tabular}{|c|c|c|c|c|c|}
\hline & $N$ & Cortisol (g/dl) & $\begin{array}{l}\text { Aldosterone } \\
\text { (ng/dl) }\end{array}$ & $\begin{array}{l}\mathrm{Na}(\mathrm{mEq} / \\
\text { liter) }\end{array}$ & $\begin{array}{c}\mathrm{K} \text { (mEq/ } \\
\text { liter) }\end{array}$ \\
\hline Normal & 6 & $8.5 \pm 1.7^{2}$ & $17.6 \pm 4.3^{2}$ & $141 \pm 3.1^{3}$ & $5.1 \pm 0.1^{2}$ \\
\hline Anephric & 6 & $17.7 \pm 2.4$ & $46.5 \pm 6.1$ & $130 \pm 3.0$ & $10 \pm 0.5$ \\
\hline
\end{tabular}

probably responsible for the elevated base line aldosterone levels in the anephric animals (Fig. 3, Table 2).

\section{CONCLUSION}

The renin-angiotensin-aldosterone system is activated in the newborn lamb. Angiotensin II is contributing to the maintenance of blood pressure and exerting an inhibitory effect on renin secretion. The newborn kidney seems to be the major source of the high circulating PRA levels.

\section{REFERENCES AND NOTES}

1. Bayard, F., Cooke, C. R., Tiller, D. H., Beitins, I. Z., Kowarsky, A., Walker, W., Gordon, W. G., and Migeon, C. J.: The regulation of aldosterone secretion in anephric man. J. Clin. Invest., 50: 1585 (1971).

2. Beitins, I. Z., Bayard, F., Levitsky, L., Ances, I. G., Kowarski, A., and Migeon, C. J.: Plasma aldosterone concentration at delivery and during the newborn period. J. Clin. Invest., 51: 386 (1972).

3. Blair-West, J. R., Coghlan, J. R., Denton, D. A., Funder, J. W., Scoggins, B. A., and Wright, R. D.: Inhibition of renin secretion by systemic and intrarenal angiotensin infusion. Am. J. Physiol., 220: 1309 (197I).

4. Godard, C., Gaillard, R., and Vallotton, M. D.: The renin-angiotensin-aldosterone system in mother and fetus at term. Nephron, 17: 353 (1976).

5. Haber, E., Koerner, T., Page, L. B., Kliman, B., and Purnode, A.: Application of a radioimmunoassay for angiotensin I in normal subjects. J. Clin. Endocrinol. Metab., 29: 1349 (1969).

6. Hollenberg, N. K., Williams, G. H., Burger, B., Ishikawa, I., and Adams, D. R.: Blockade and stimulation of renal, adrenal and vascular angiotensin II receptors with I-sar, 8-ala angiotensin II in normal man. J. Clin. Invest., 57: 39 (1976).

7. Ito, T., Woo, J., Hening, R., and Horton, R.: A radioimmunoassay for aldosterone in human peripheral plasma including a comparison of alternate techniques. J. Clin. Endocrinol. Metab., 34: 106 (1972).

8. Johnson, J. A., and Davis, J. O.: Angiotensin II: important role in the maintenance of arterial blood pressure. Science, 179: 906 (1973).

9. Johnson, J. A., and Davis, J. O.: Effects of a specific competitive antagonist of angiotensin II on arterial pressure and adrenal steroid secretion in dogs. Circ. Res., 32(suppl 1): 159 (1973).

10. Kotchen. T. A., Strickland, A. L., Rice, T. W., and Walters, D. R.: A study of the renin-angiotensin system in newborn infants. J. Pediatr. 80: 938 (1972).

11. Leake, R. D., Williams, P. R., and Oh, W.: Validity of neonatal blood pressure obtained by the manometric method. Pediatrics, 52: 293 (1973).

12. McDonald, K. M., Taher, S., Aisenbrey, G., de Torrente, A., and Schier, R. W.: Effect of angiotensin II and angiotensin II inhibitor on renin secretion in the dog. Am. J. Physiol., 228: 1562 (1975).

13. Noth, R. H., Tan, S. Y., and Mulrow, P. J.: Effects of angiotensin II blockade by saralasin in normal man. J. Clin. Endocrinol. Metab., 45: 10 (1977).

14. Radioimmunology Manual, 3rd edition, p. 25, 84 (Nichols Institute of Endocrinology, San Pedro, CA, (976).

15. Siegel, S. R., and Fisher, D. A.: The renin-angiotensin-aldosterone system in the newborn lamb: response to furosemide. Pediatr. Res., /1: 837 (1977).

16. Siegel, S. R., Fisher, D. A., and Oh, W.: Serum aldosterone concentrations related to sodium balance in the newborn infant. Pediatrics, 53: 410 (1974).

17. Skinner, S. L.: Improved assay methods for renin concentration and activity in human plasma. Cir. Res., 22: 391 (1967).

18. Vander, A. J., and Geelhoed, G. W.: Inhibition of renin secretion by angiotensin II. Proc. Soc. Exp. Biol. Med., 120: 399 (1965).

19. The authors thank Norwich Pharmacol Co., Norwich, NY for supplying the saralasin acetate and Hoerhst-Roussel Pharmaceuticals, Somerville, NJ for providing the Lasix.

20. This research was supported by grant HD 10611 -01 from the National Institute of Child Health and Human Development of The National Institutes of Health.

21. Requests for reprints should be addressed to: Sharon R. Siegel, M.D., Harbor General Hospital, 1000 West Carson Street. Torrance, CA 90509, USA.

22. Received for publication February 23, 1978.

23. Accepted for publication May 18, 1978. 